\title{
A Comparative Analysis of Customers' Satisfaction of Telecommunications Industries: A Reference from Bangladesh
}

\author{
Mohammad Kamrul Ahsan
}

Assistant Professor, Department of Business Administration, Metropolitan University, Sylhet, BANGLADESH

*Corresponding Contact:

Email: ahsan404243@gmail.com

\begin{abstract}
This is basically an analytic paper. Here the researcher has made a comparative analysis of customers' satisfaction of Banglalink, Grameen Phone, Robi and Teletalk Telecommunication Companies in Bangladesh. An ordered questionnaire is organized to collect primary data from 400 customers from the customer care centers in the Sylhet City from Bangladesh. The researcher uses random and convenience sampling methods in this paper to collect data. The researcher selects fifteen independent variables to compare the customers' satisfaction. Descriptive statistics, t-statistics, and ANOVA have been used in here to analyze the data. The findings have shown that the customers of Robi Telecommunication Company are more satisfied than the other companies. The researcher has thought that this effect may be the effect of merging with Robi and Airtel.
\end{abstract}

Key Words: Comparative analysis, Telecommunication Companies, Customers' satisfaction

\section{INTRODUCTION}

Portable media transmission industry has ended up being to a great degree aggressive in wherever all through the world. Directly a-days customers consider distinctive components before picking an organization overseer. 'Consumer loyalty' is both an objective and a showcasing instrument for client-focused organizations (Kotler and Keller, 2012). The portable market of Bangladesh is exceptionally appealing at this point. The enthusiasm of the clients towards cell phone is expanding step by step. Accordingly, organizations are attempting to catch the most extreme share of the market by giving different administrations to fulfill the client (Haque, et al., 2011). Basically, this is an analytic paper. The researcher has made a comparative analysis of the customers' satisfaction. The different customers have the different exceptions from their operators. The objective of this study is to make comparisons, and identify major causes of differences of the level of satisfaction of customers of Banglalink, Grameen Phone, Robi, and Teletalk.

Research Questions: Are there any differences in the level of satisfaction among the customers of Banglalink, Grameen Phone, Robi, and Teletalk? 


\section{REseARCH Methods}

Some Clarifications:

\begin{tabular}{lcc} 
Full Name of the Company & Short Form & Color \\
\hline Banglalink Digital Communications Limited & BL & \\
\hline Grameen Phone Limited & GP \\
\hline Robi Axiata Limited & Robi & \\
\hline Teletalk Bangladesh Limited & TT & \\
\hline
\end{tabular}

Here, the researcher has used the short form of Banglalink Digital Communications Limited as 'BL', and Grameen Phone Limited as 'GP', Robi Axiata Limited as 'Robi', and Teletalk Bangladesh Limited as 'TT' use these colors to identify these objects easily. All the customers of Airtel are treated as the customers of Robi (Husain, 2016).

Data collection period: January to February 2017.

Data collection area: Sylhet City, Bangladesh.

Population: All the customers of Sylhet City are addressed as the population in this paper.

Sampling size: The sample size of this study is 400 (100 BL, 100 BL, 100 Robi and 100 TT).

Sampling procedures: The researcher has used the combination of random and convenience sampling methods in this study. Data have been collected from the different part of the Sylhet city and mostly from the in front of the customer care center of the mobile telecommunication companies.

Sample characteristics: The respondents were picked regardless of sex, age, salary, training, occupation, religion, area.

Instruments: The primary data have been collected by using a structured questionnaire from the 400 customers among them, BL Customers are 100, GP Customers are 100, Robi customers are 100, and TT customers are 100 in numbers. The questionnaire has two parts: 1. Demographic information and 2. Selected variables. Here researchers select fifteen variables to measure the customers' satisfaction and one variable is dependent variable i.e., overall satisfaction. These variables are rated by Five Points Likert Scale. These are $1=$ Strongly Dissatisfied, 2=Dissatisfied, 3=Average, 4=Satisfied, 5=Strongly Satisfied. The Researcher uses MS excel 2007 to analysis the data i.e., descriptive statistics, $t$-statistics, and ANOVA. Variables are represented by a bar, line, and column charts with mean values to compare satisfactions of BL, GP, Robi, and TT of customers.

The researcher has referred to various books, journals, and periodicals as the vital source of secondary data.

\section{Research Assumptions}

$\mathrm{H}_{\mathrm{A} 1}$ : There is a significant difference between the satisfaction of customers of $\mathrm{BL}, \mathrm{GP}$, Robi, and TT. $\left(\mathrm{H}_{\mathrm{A} 1}: \neq \mathrm{GP} \neq\right.$ Robi $\left.\neq \mathrm{TT}\right)$

Ha2: There is a significant difference between the satisfaction of customers of BL and GP. $\left(\mathrm{H}_{\mathrm{A} 2}: \mathrm{BL} \neq \mathrm{GP}\right)$

$\mathrm{H}_{\mathrm{A} 3}$ : There is a significant difference between the satisfaction of customers of BL and Robi. (HA3: $\mathrm{BL} \neq$ Robi) 
HA4: There is a significant difference between the satisfaction of customers of BL and TT. $\left(\mathrm{H}_{\mathrm{A} 4:} \mathrm{BL} \neq \mathrm{TT}\right)$

$\mathrm{H}_{\mathrm{A5}}$ : There is a significant difference between the satisfaction of customers of GP and Robi. (HA5: GP $\neq$ Robi)

$\mathrm{H}_{\mathrm{A} 6}$ : There is a significant difference between the satisfaction of customers of GP and TT. $\left(\mathrm{H}_{\mathrm{A} 6}: \mathrm{GP} \neq \mathrm{TT}\right)$

$\mathrm{H}_{\mathrm{A} 7}$ : There is a significant difference between the satisfaction of customers of Robi and TT. (Hat: Robi $\neq$ TT)

\section{Limitations}

It is difficult to show the true picture by the sampling of only 400 customers. This sampling area is in Sylhet, so it is difficult to show the true picture all over Bangladesh. Moreover, most of the customers are young in age. So it is difficult to show the true.

\section{DATA ANALYSIS}

Table 1: Demographic Profile (\%)

\begin{tabular}{|c|c|c|c|c|}
\hline Demographic Profile & BL & GP & Robi & TT \\
\hline \multicolumn{5}{|l|}{ Gender } \\
\hline Male & 61 & 77 & 63 & 70 \\
\hline Female & 39 & 23 & 37 & 30 \\
\hline \multicolumn{5}{|l|}{ Age (Years) } \\
\hline Less than 20 & 30 & 20 & 25 & 27 \\
\hline 21 to 25 & 65 & 79 & 70 & 64 \\
\hline 26 to 30 & 4 & 1 & 5 & 6 \\
\hline Over 30 & 1 & 0 & 0 & 3 \\
\hline \multicolumn{5}{|l|}{ Education } \\
\hline SSC/HSC & 27 & 17 & 22 & 14 \\
\hline Bachelor & 62 & 76 & 69 & 75 \\
\hline Masters & 8 & 7 & 6 & 11 \\
\hline Others & 3 & 0 & 3 & 0 \\
\hline \multicolumn{5}{|l|}{ Religion } \\
\hline Muslim & 74 & 77 & 81 & 82 \\
\hline Hindu & 22 & 21 & 18 & 15 \\
\hline Christian & 3 & 1 & 1 & 3 \\
\hline Buddhists & 1 & 1 & 0 & 0 \\
\hline \multicolumn{5}{|l|}{ Marital Status } \\
\hline Married & 12 & 8 & 15 & 20 \\
\hline Unmarried & 88 & 92 & 85 & 80 \\
\hline
\end{tabular}

Source: Author's analysis of research data, (2017)

From the above table, it is seen that most of the customers are male (BL-61\%, GP-77\%, Robi$63 \%$ and TT-70\%), in the age group of $21-25$ years (BL-65\%, GP-79\%, Robi-70\% and TT-64\%), level of education is a bachelor degree (BL-62\%, GP-76\%, Robi- $69 \%$ and TT-75\%), in the religion of Muslims (BL-74\%, GP-77\%, Robi-81\% and TT- $\%$ ), and unmarried (BL-88\%, GP92\%, Robi-85\% and TT-80\%). 
Table 2: Basic Operator and Satisfaction Information

\begin{tabular}{|c|c|c|c|c|}
\hline Basic Operator Information & BL & GP & Robi & TT \\
\hline Experience of Use Phones (Years) & & & & \\
\hline Less than 1 & 12 & 2 & 13 & 6 \\
\hline $1-3$ & 34 & 31 & 23 & 32 \\
\hline $3-5$ & 31 & 31 & 34 & 20 \\
\hline $5-7$ & 14 & 18 & 18 & 21 \\
\hline $7-9$ & 6 & 18 & 9 & 12 \\
\hline Over 9 & 3 & 0 & 3 & 9 \\
\hline Type of SIM & & & & \\
\hline Pre-paid & 88 & 97 & 95 & 91 \\
\hline Post-paid & 12 & 3 & 5 & 9 \\
\hline You Like Most & & & & \\
\hline Grameen Phone & 18 & 72 & 11 & 11 \\
\hline Banglalink & 59 & 9 & 3 & 0 \\
\hline Robi/Airtel & 12 & 19 & 84 & 13 \\
\hline Teletalk & 11 & 0 & 2 & 76 \\
\hline Your Recommendation for the First User & & & & \\
\hline Grameen Phone & 22 & 70 & 10 & 16 \\
\hline Banglalink & 51 & 6 & 5 & 0 \\
\hline Robi/Airtel & 14 & 21 & 78 & 15 \\
\hline Teletalk & 13 & 3 & 7 & 69 \\
\hline S analysis of & & &
\end{tabular}

Source: Author's analysis of research data, (2017)

From the above table, it is seen that most of the customers have the experience of using phones 1 to 5 years and they use pre-paid SIM card. The researcher has asked a question to the customer that "Which Operator do you like most?" The result is shown in figure 1. Most of them like their own telecommunication company (BL-59\%, GP-72\%, Robi- $84 \%$ and TT$76 \%$ ). Customers of Robi are large in numbers who are satisfied most by answering this question.

Figure 1: You like most

\section{You Like Most}

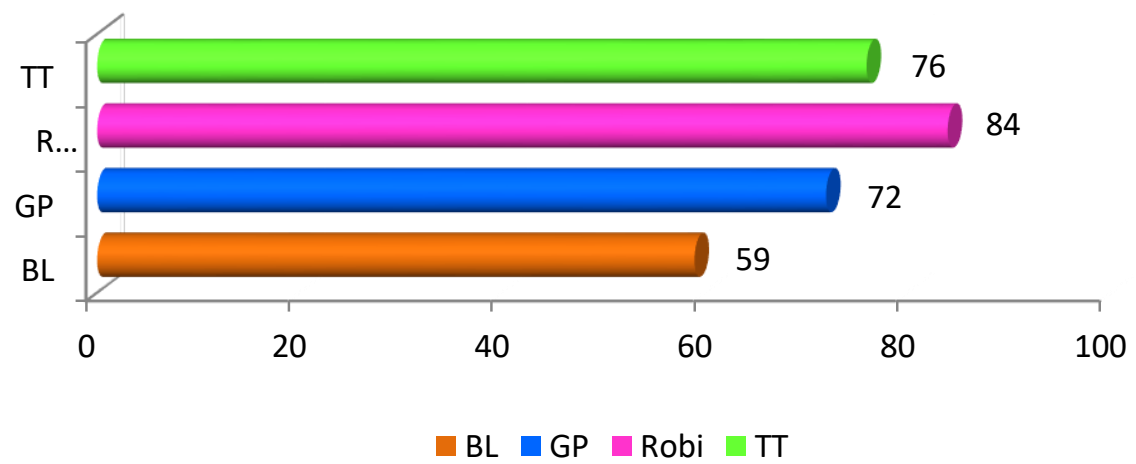

Source: Author's analysis of research data, (2017) 
Figure 2: Your suggestion for the First User

\section{Your Suggestion for the First User}

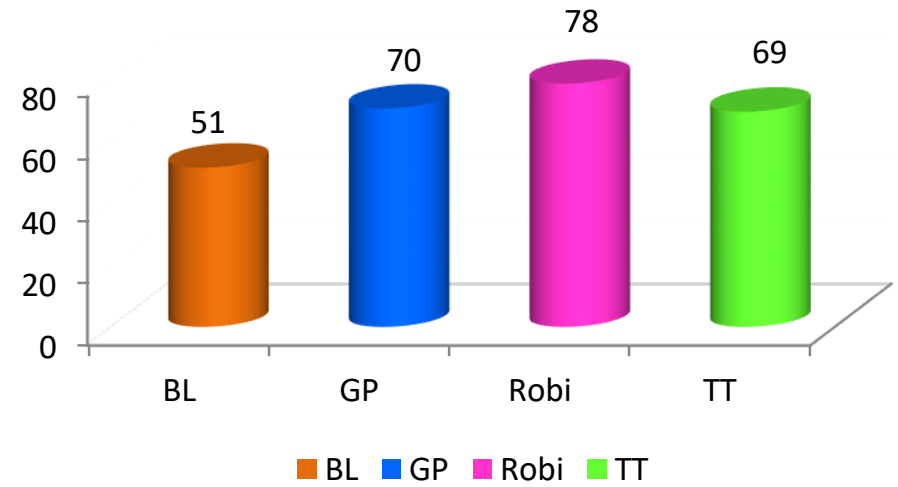

Source: Author's analysis of research data, (2017)

The researcher has asked another question to the customer that "Which Operator do you suggest for the First User?" The result has shown in the above figure 2. Most of them suggest their own telecommunication company (BL-51\%, GP-70\%, Robi-78\% and TT-69\%). The customers of Robi are large in numbers who suggest their own company most.

\section{VARIABLES FOR COMPARING SATISFACTION}

Figure 3: Tariff: On-Net

\section{Tariff: On-Net}

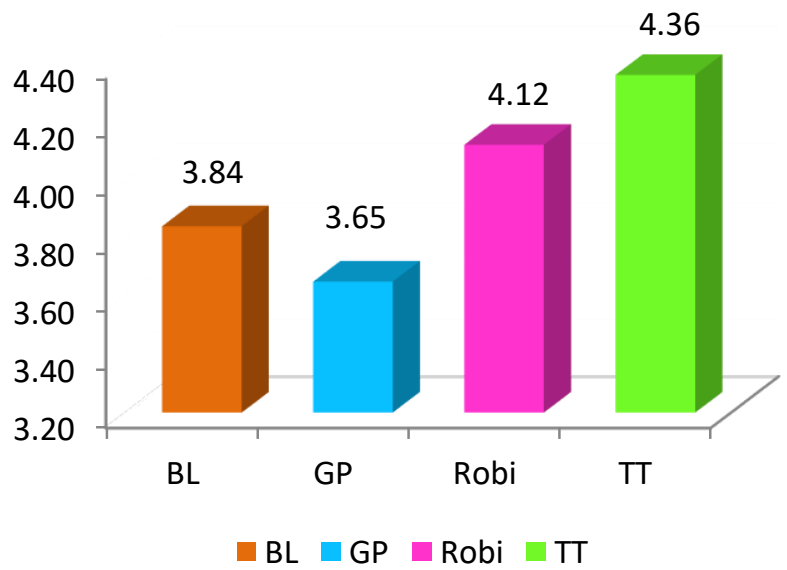

Source: Author's analysis of research data, (2017)

From the above figure, it is clear that the customers of Teletalk are enjoying most favorable call rate on the same operator. They are most satisfied on tariff on-net. After that, the customers of Robi, Banglalink, and Grameen phone are enjoying the call rate of same operators. 
Figure 4: Tariff: Off-Net

\section{Tariff: Off-Net}

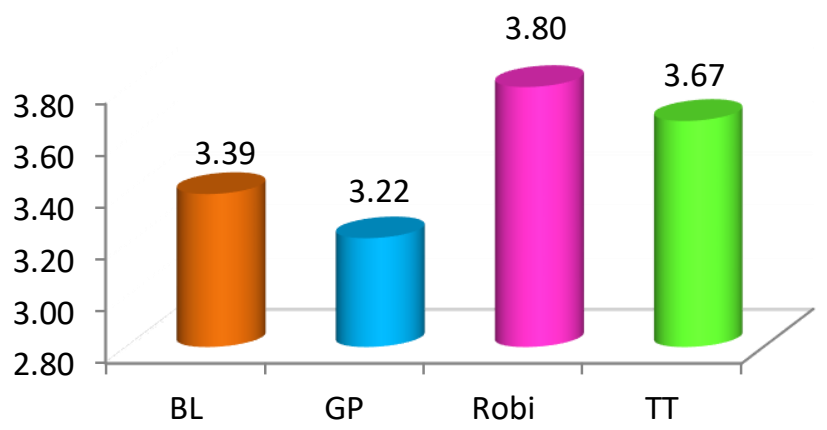

$\square \mathrm{BL} \square \mathrm{GP} \square$ Robi $\square \mathrm{T}$

Figure 5: Tariff: International Calls

\section{Tariff: International Calls}

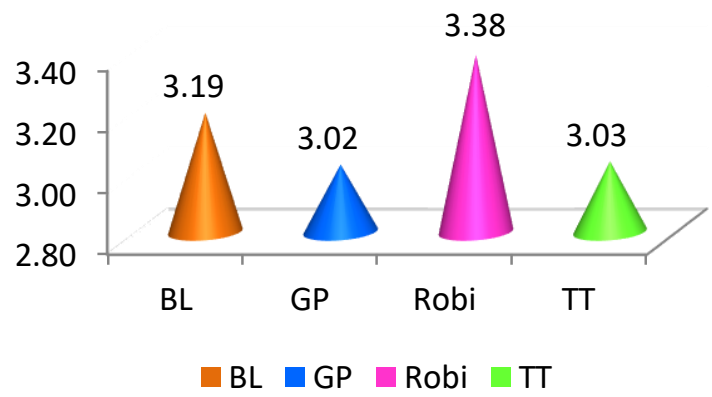

Figure 6: Tariff: FnF

\section{Tariff: FnF}

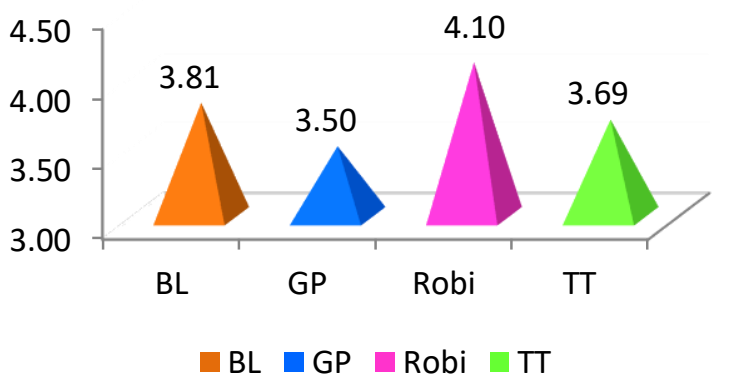

Source: Author's analysis of research data, (2017)

From the above figure no. 4, 5, and 6, it is seen that the customers of Robi enjoy more satisfaction of call rate of off-net calls, international calls, and FnF calls. 
Figure 7: Number of FnF

Number of FnF

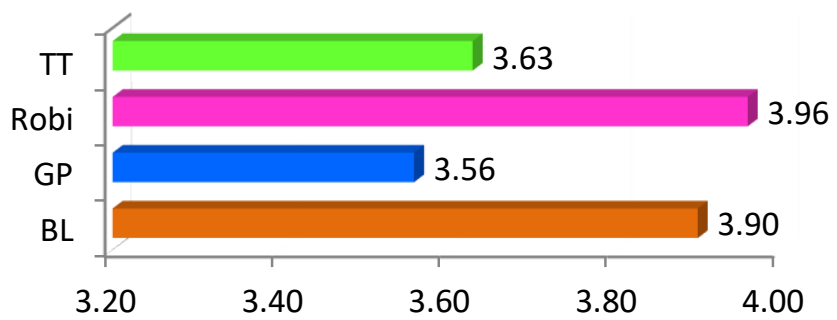

$B L \square G P \square$ Robi $\square T T$

Figure 8: Network Coverage

\section{Network Coverage}

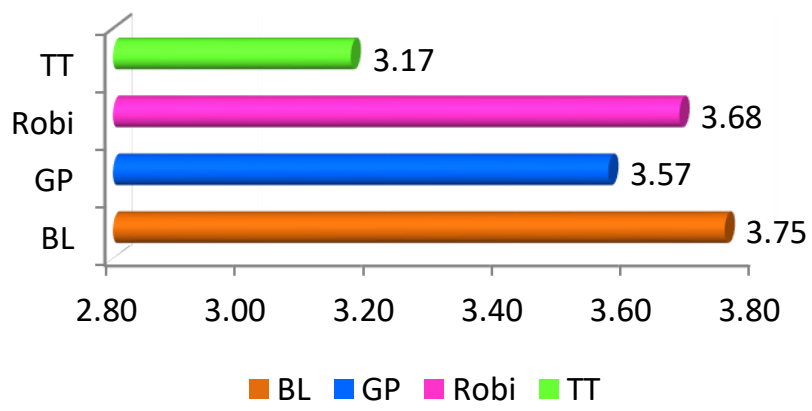

Figure 9: Network Quality

\section{Network Quality}

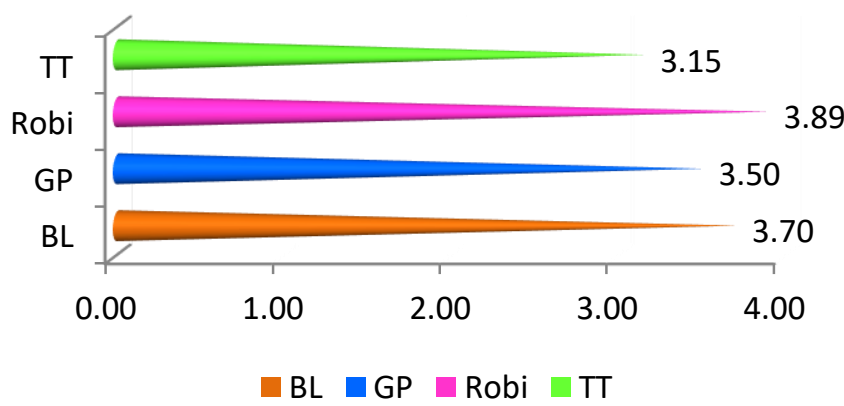

Source: Author's analysis of research data, (2017)

From the above figure 7,8, and 9, it is seen that the customers of Robi enjoy more satisfaction of a number of FnF, network coverage, and network quality. Then the customers of Banglalink are in the second position. 
Figure 10: Internet Services

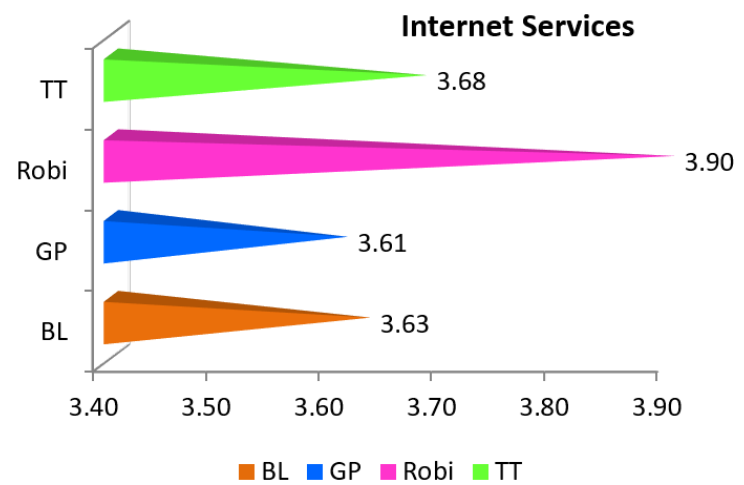

Source: Author's analysis of research data, (2017)

From the above figure 10, it is seen that the customers of Robi enjoy more satisfaction of internet services. Then the customers of Teletalk are in the second position.

Figure 11: Availability of customer care centers

\section{Availability of Customer Care Centers}

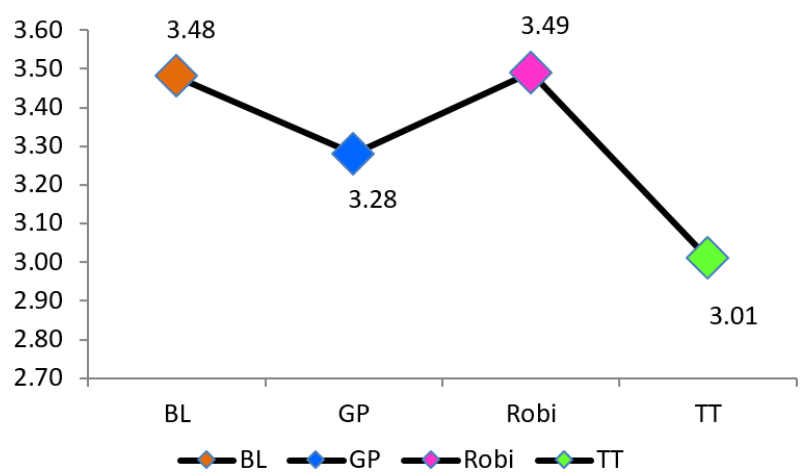

Source: Author's analysis of research data, (2017)

Available customer care centers help the customers when they need. From the above figure, it is clear that the customers of Robi enjoy this benefit more. Then the customers of Banglalink enjoy the same benefit.

Figure 12: Behavior of personnel in Customer Service

\section{Behavior of personnel in Customer Service}

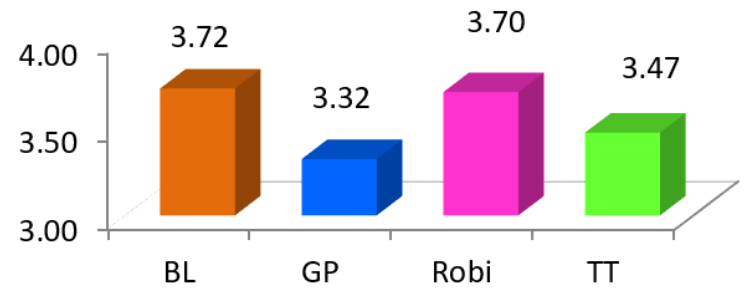

$\square \mathrm{BL} \quad \mathrm{GP} \square$ Robi $\square \mathrm{TT}$

Source: Author's analysis of research data, (2017) 
The behavior of personnel in customer care centers is another important variable to measure the satisfaction. In this way, the above figure shows that the customers of Banglalink enjoy the best behavior from the personnel of customer services. Then the second position is Robi.

Figure 13: Availability of recharge point

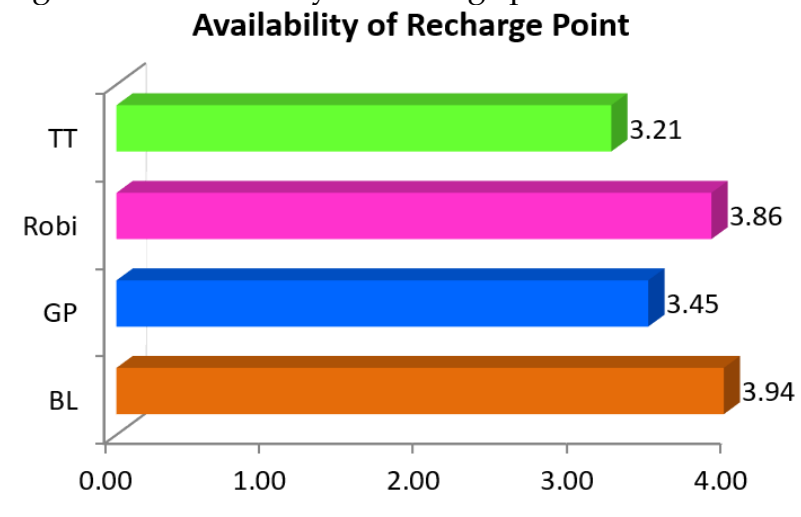

$\square \mathrm{BL} \backsim \mathrm{GP} \square$ Robi $\square \mathrm{TT}$

Source: Author's analysis of research data, (2017)

Available recharge points are the important tools to measure the customers' satisfaction. The above figure shows that the customers of Banglalink enjoy more recharge points. Then the second position is Robi.

Figure 14: Validity period of recharge amount

\section{Validity period of Recharge amount}

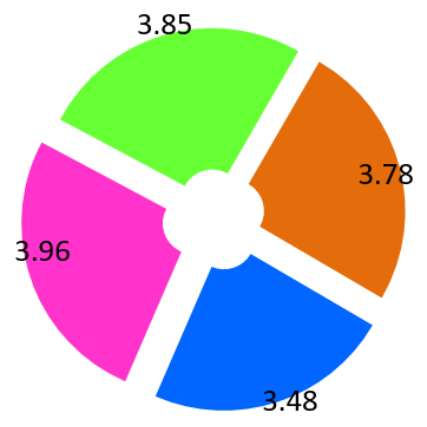

$\square \mathrm{BL} \square \mathrm{GP} \square$ Robi $\square \mathrm{TT}$

Figure 15: Bill payment system

\section{Bill Payment System}

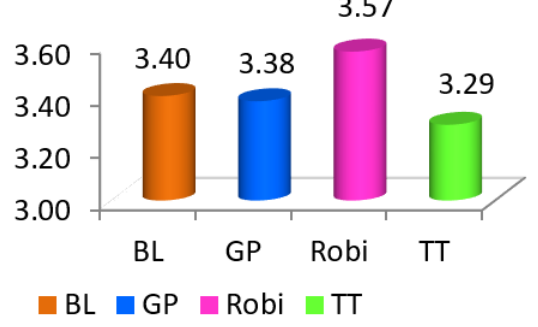


Figure 16: Promotional Offer

\section{Promotional Offers}

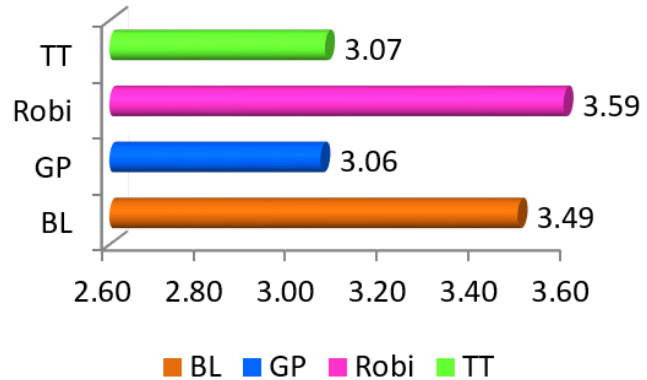

Source: Author's analysis of research data, (2017)

From the above figure 14, 15, and 16, it is seen that the customers of Robi enjoy more facilities than the other operators. They are more satisfied regarding validity period of recharge amount, bill payment system, and promotional offers. The second position is Banglalink.

Figure 17: Value-added services

\section{Value Added Services}

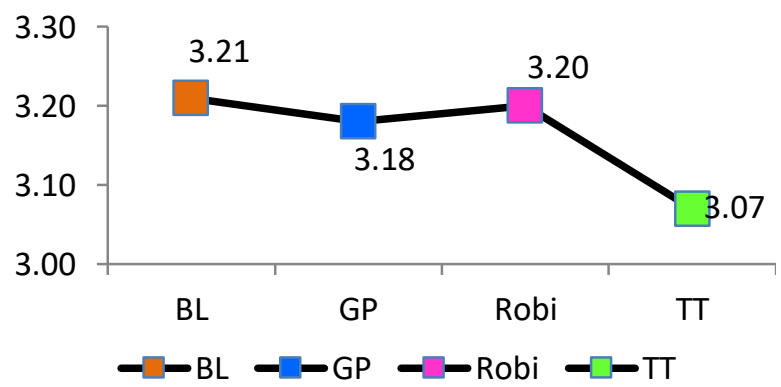

Source: Author's analysis of research data, (2017)

From the above figure, it is clear that Banglalink is the number one value-added service provider and then Robi is in the second position.

Figure 18: Your overall satisfaction considering the above influencing factors

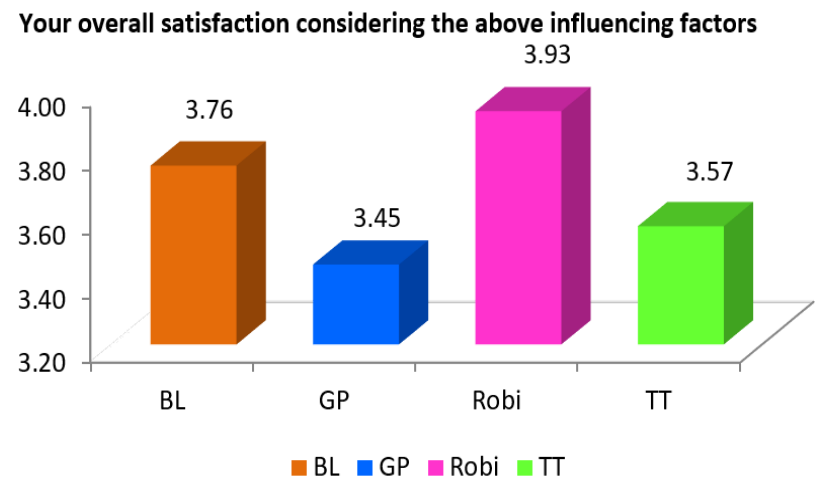

Source: Author's analysis of research data, (2017) 
From the above figure, it is clear that the customers of Robi are the most satisfied customers. By the measuring overall satisfaction, the customers of Robi show the most satisfaction and then Banglalink.

Table 3: Descriptive Statistics

\begin{tabular}{|l|c|c|c|c|c|c|c|c|}
\hline \multicolumn{1}{|c|}{ Descriptive } & \multicolumn{2}{c|}{ BL } & \multicolumn{2}{c|}{ GP } & \multicolumn{2}{c|}{ Robi } & \multicolumn{2}{c|}{ Taletalk } \\
\hline & Mean & SD & Mean & SD & Mean & SD & Mean & SD \\
\hline T_O Net & 3.84 & 0.98 & 3.65 & 1.20 & 4.12 & 0.10 & 4.36 & 0.08 \\
\hline T_Off-Net & 3.39 & 1.02 & 3.22 & 1.12 & 3.80 & 0.12 & 3.67 & 0.10 \\
\hline T_I_Calls & 3.19 & 1.32 & 3.02 & 1.18 & 3.38 & 0.10 & 3.03 & 0.12 \\
\hline T_FnF & 3.81 & 1.22 & 3.50 & 1.24 & 4.10 & 0.11 & 3.69 & 0.12 \\
\hline N_FnF & 3.90 & 1.04 & 3.56 & 1.22 & 3.96 & 0.10 & 3.63 & 0.12 \\
\hline N_Coverage & 3.75 & 1.11 & 3.57 & 1.03 & 3.68 & 0.10 & 3.17 & 0.11 \\
\hline N_Quality & 3.70 & 1.00 & 3.50 & 1.03 & 3.89 & 0.10 & 3.15 & 0.10 \\
\hline I_Services & 3.63 & 1.15 & 3.61 & 1.14 & 3.90 & 0.10 & 3.68 & 0.11 \\
\hline A_C_C_Centers & 3.48 & 1.15 & 3.28 & 1.17 & 3.49 & 0.11 & 3.01 & 0.12 \\
\hline B_C_Service & 3.72 & 1.05 & 3.32 & 1.10 & 3.70 & 0.11 & 3.47 & 0.12 \\
\hline A_R_Point & 3.94 & 1.06 & 3.45 & 1.04 & 3.86 & 0.11 & 3.21 & 0.13 \\
\hline V_R_amount & 3.78 & 1.12 & 3.48 & 1.05 & 3.96 & 0.10 & 3.85 & 0.10 \\
\hline B_P_System & 3.40 & 1.21 & 3.38 & 1.11 & 3.57 & 0.10 & 3.29 & 0.13 \\
\hline V_A_Services & 3.21 & 1.21 & 3.18 & 1.17 & 3.20 & 0.12 & 3.07 & 0.13 \\
\hline P_Offers & 3.49 & 1.10 & 3.06 & 1.17 & 3.59 & 0.11 & 3.07 & 0.12 \\
\hline O_S & 3.76 & 0.84 & 3.45 & 1.12 & 3.93 & 0.08 & 3.57 & 0.09 \\
\hline
\end{tabular}

Source: Author's analysis of research data, (2017)

This table shows the customers' satisfaction of all operators at a glance.

\section{TEST OF ASSUMPTIONS}

\section{$\mathrm{H}_{\mathrm{A} 1}: \mathrm{BL} \neq \mathrm{GP} \neq \mathrm{Robi} \neq \mathrm{TT}$ \\ Anova: Single Factor \\ SUMMARY}

\begin{tabular}{|c|c|c|c|c|c|c|}
\hline Groups & Count & Sum & Average & Variance & & \\
\hline $\mathrm{BL}$ & 16 & 57.99 & 3.624375 & 0.055626 & & \\
\hline GP & 16 & 54.23 & 3.389375 & 0.036846 & & \\
\hline Robi & 16 & 60.13 & 3.758125 & 0.067203 & & \\
\hline TT & 16 & 54.92 & 3.4325 & 0.13998 & & \\
\hline \multicolumn{7}{|l|}{ ANOVA } \\
\hline SOURCE OF VARIATION & SS & $d f$ & MS & $F$ & P-value & F crit \\
\hline Between Groups & 1.415192 & 3 & 0.471731 & 6.296976 & 0.000872 & 2.758078 \\
\hline Within Groups & 4.494831 & 60 & 0.074914 & & & \\
\hline Total & 5.910023 & 63 & & & & \\
\hline
\end{tabular}

The first assumption was that there is a significant difference between the satisfaction of customers of BL, GP, Robi, and TT. This assumption is proved by the analysis of ANOVA: Single Factor. Here F-test is highly significant. So, the assumption is proved. 


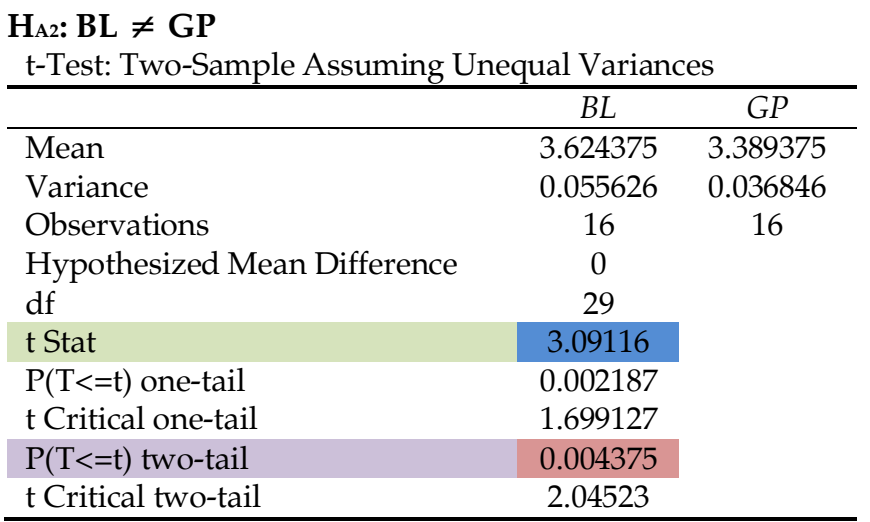

The second assumption was that there is a significant difference between the satisfaction of customers of BL, and GP. This assumption is proved by the analysis of $\mathrm{t}$-Test: Two-Sample Assuming Unequal Variances. Here t-stat is highly significant. So, the assumption is proved.

$\mathrm{H}_{\mathrm{A} 3}: \mathrm{BL} \neq$ Robi

t-Test: Two-Sample Assuming Unequal Variances

\begin{tabular}{lcc}
\hline & $B L$ & Robi \\
\hline Mean & 3.624375 & 3.758125 \\
Variance & 0.055626 & 0.067203 \\
Observations & 16 & 16 \\
Hypothesized Mean Difference & 0 & \\
df & 30 & \\
t Stat & -1.52652 & \\
$\mathrm{P}(\mathrm{T}<=\mathrm{t})$ one-tail & 0.068678 & \\
$\mathrm{t}$ Critical one-tail & 1.697261 & \\
$\mathrm{P}(\mathrm{T}<=\mathrm{t})$ two-tail & 0.137355 & \\
$\mathrm{t}$ Critical two-tail & 2.042272 & \\
\hline
\end{tabular}

The third assumption was that there is a significant difference between the satisfaction of customers of BL and Robi. But this assumption is not proved by the analysis of $t$-Test: Two-Sample Assuming Unequal Variances. Here t-stat is not significant. So, it can't be proved the assumption, i.e. there is no significant difference between the satisfaction of customers of BL and Robi.

$\mathrm{H}_{\mathrm{A} 4}: \mathrm{BL} \neq \mathrm{TT}$

t-Test: Two-Sample Assuming Unequal Variances

\begin{tabular}{lcc}
\hline & $B L$ & $T T$ \\
\hline Mean & 3.624375 & 3.4325 \\
Variance & 0.055626 & 0.13998 \\
Observations & 16 & 16 \\
Hypothesized Mean Difference & 0 & \\
$\mathrm{df}$ & 25 & \\
$\mathrm{t}$ Stat & 1.73535 & \\
$\mathrm{P}(\mathrm{T}<=\mathrm{t})$ one-tail & 0.047496 & \\
$\mathrm{t}$ Critical one-tail & 1.708141 & \\
$\mathrm{P}(\mathrm{T}<=\mathrm{t})$ two-tail & 0.094992 & \\
$\mathrm{t}$ Critical two-tail & 2.059539 & \\
\hline
\end{tabular}

The fourth assumption was that there is a significant difference between the satisfaction of customers of BL and TT. But this assumption is not proved by the analysis of t-Test: Two-Sample 
Assuming Unequal Variances. Here t-stat is not significant. So, it can't be proved the assumption, i.e. there is no significant difference between the satisfaction of customers BL and TT.

HAs: $_{\text {AP }} \neq$ Robi

t-Test: Two-Sample Assuming Unequal Variances

\begin{tabular}{lcc}
\hline & $G P$ & Robi \\
\hline Mean & 3.389375 & 3.758125 \\
Variance & 0.036846 & 0.067203 \\
Observations & 16 & 16 \\
Hypothesized Mean Difference & 0 & \\
$\mathrm{df}$ & 28 & \\
$\mathrm{t}$ Stat & -4.5727 & \\
$\mathrm{P}(\mathrm{T}<=\mathrm{t})$ one-tail & 0.0000 & \\
$\mathrm{t} C$ ritical one-tail & 1.701131 & \\
$\mathrm{P}(\mathrm{T}<=\mathrm{t})$ two-tail & 0.00009 & \\
$\mathrm{t} C$ ritical two-tail & 2.048407 & \\
\hline
\end{tabular}

The fifth assumption was that there is a significant difference between the satisfaction of customers of GP and Robi. This assumption is proved by the analysis of $\mathrm{t}$-Test: Two-Sample Assuming Unequal Variances. Here t-stat is highly significant. So, the assumption is proved.

$\mathrm{H}_{\mathrm{A6}}: \mathrm{GP} \neq \mathrm{TT}$

t-Test: Two-Sample Assuming Unequal Variances

\begin{tabular}{lcc}
\hline & $G P$ & $T T$ \\
\hline Mean & 3.389375 & 3.4325 \\
Variance & 0.036846 & 0.13998 \\
Observations & 16 & 16 \\
Hypothesized Mean Difference & 0 & \\
$\mathrm{df}$ & 22 & \\
$\mathrm{t}$ Stat & -0.41022 & \\
$\mathrm{P}(\mathrm{T}<=\mathrm{t})$ one-tail & 0.342806 & \\
$\mathrm{t}$ Critical one-tail & 1.717144 & \\
$\mathrm{P}(\mathrm{T}<=\mathrm{t})$ two-tail & 0.685613 & \\
$\mathrm{t}$ Critical two-tail & 2.073873 & \\
\hline
\end{tabular}

The sixth assumption was that there is a significant difference between the satisfaction of customers of GP and TT. But this assumption is not proved by the analysis of $\mathrm{t}$-Test: Two-Sample Assuming Unequal Variances. Here t-stat is not significant. So, it can't be proved the assumption, i.e. there is no significant difference between the satisfaction of customers of GP and TT.

$\mathrm{H}_{\mathrm{A} 7}$ : Robi $\neq \mathrm{TT}$

t-Test: Two-Sample Assuming Unequal Variances

\begin{tabular}{lcc}
\hline & Robi & TT \\
\hline Mean & 3.758125 & 3.4325 \\
Variance & 0.067203 & 0.13998 \\
Observations & 16 & 16 \\
Hypothesized Mean Difference & 0 & \\
df & 27 & \\
t Stat & 2.861546 & \\
P $(\mathrm{T}<=$ t) one-tail & 0.004022 & \\
t Critical one-tail & 1.703288 & \\
P $(T<=t)$ two-tail & 0.008045 & \\
t Critical two-tail & 2.05183 & \\
\hline
\end{tabular}


The last and seventh assumption was that there is a significant difference between the satisfaction of customers of Robi and TT. This assumption is also proved by the analysis of $\mathrm{t}-$ Test: Two-Sample Assuming Unequal Variances. Here t-stat is highly significant. So, the assumption is proved.

Results of the Test of the Assumptions at A Glance

\begin{tabular}{|c|c|c|}
\hline Numbers of Assumptions & Assumptions & Results \\
\hline$H_{\mathrm{A} 1}$ & BL $\neq$ GP $\neq$ Robi $\neq$ TT & Proved \\
\hline$H_{\mathrm{A} 2}$ & BL $\neq$ GP & Proved \\
\hline$H_{\mathrm{A} 3}$ & BL $\neq$ Robi & Isn't proved \\
\hline$H_{\mathrm{A} 4}$ & BL $\neq$ TT & Isn't proved \\
\hline$H_{\mathrm{A} 5}$ & GP $\neq$ Robi & Proved \\
\hline$H_{\mathrm{A} 6}$ & GP $\neq$ TT & Isn't proved \\
\hline$H_{\mathrm{A} 7}$ & Robi $\neq$ TT & Proved \\
\hline
\end{tabular}

\section{CONCLUSION}

Finally, the researcher has made a rank order on the basis of customers' satisfaction.

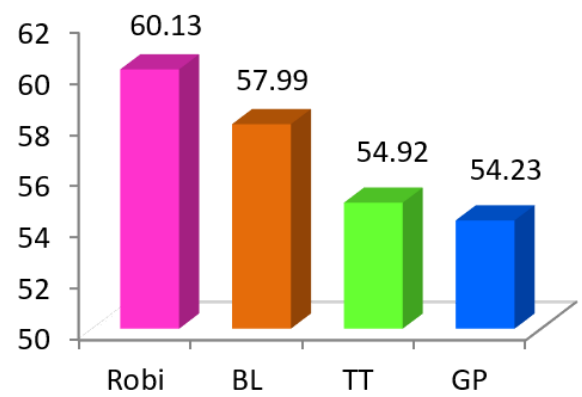

Source: Author's analysis of research data, (2017)

It is seen that the customers of Robi are the happiest customers by using Robi. The researcher has thought that this case may be the effect of merging with Airtel. Then Banglalink is in the second position. The customers of Grameen Phone and Teletalk are expecting more than they have got. So, the authority of Grameen Phone and Teletalk should take care about these variables.

\section{REFERENCES}

Haque, A. Nuruzzaman \& Kalam, A. (2011). Customer Satisfaction Mobile Phone Services: An Empirical Study on Grameen Phone (GP) and Banglalink (BL) in Bangladesh, International Business Management, 5(3), 140-150, 2011, ISSN: 1993-5250

Husain, I. (2016). "Robi-Airtel Merger Sets out on Commercial Journey." Dhaka Tribune. N.p., 16 Nov. 2016. Web. Retrieved: 03 Apr. 2017 from http://www.dhakatribune.com /business /2016/11/17/robi-airtel-merger-sets-commercial-journey/

Kotler, P. \& Keller, K. L. (2012). Marketing management. 14th ed. Harlow: Prentice-Hall. ISBN-10: 0273755021.

Neogy, T. (2014). Evaluation of Efficiency of Accounting Information Systems: A Study on Mobile Telecommunication Companies in Bangladesh. Global Disclosure of Economics and Business, 3(1), 39-54. 